\title{
STRATEGI MENINGKATKAN OUTCOMES PASCA PELATIHAN VOKASI TUKANG BAHAN BANGUNAN PAVING BLOK PROGRAM KOTAKU
}

\author{
Ellys \\ Universitas IBA \\ Email: ellysthoyib@gmail.com \\ Lily Rahmawati Harahap \\ Universitas IBA \\ Email: harahaplily@gmail.com \\ R.Y.Effendi \\ Universitas IBA \\ Email:effendiry@gmail.com \\ Rahmi Aryanti \\ Universitas IBA \\ Email: rahmiaryanti@gmail.com
}

\begin{abstract}
This study aims to provide solutions to the learning outcomes achieved by participants after vocational training for paving block construction materials. The training was held on December 21-24, 2020 at the Faculty of Engineering, University of IBA Palembang. There were 40 participants. The answers to the pre-test and posttest showed that there was a change in the number of participants towards learning outcomes, namely; attitudes, knowledge, general skills and specific skills. Participants with an increased outcome of $15.625 \%$, who remained/stable $76.25 \%$ and participants with a decreased outcome were $8.125 \%$. The answers are also regressed to determine the effect of training on changes in attitudes, knowledge, general and specific skills. The results show that there is a change in attitude of $3.1 \%$, knowledge of $15.8 \%$, general skills of $19.8 \%$ and special skills of $0.2 \%$. The effect (R square) is not that big, but it is clear that vocational training has an influence on participant outcomes. It takes a goal-directed activity strategy and goal activity strategy to improve the outcome of post-training participants, so that the goal of becoming a construction material contractor for competent road and settlement construction infrastructure can be achieved.
\end{abstract}

Keywords: vocational training, attitude change, knowledge, general skills and special skills

\begin{abstract}
Abstrak
Penelitian bertujuan memberikan solusi atas capaian pembelajaran (outcome) yang dicapai peserta setelah pelatihan vokasi tukang bahan bangunan paving blok. Pelatihan dilaksanakan 21-24 Desember 2020 di Fakultas Teknik Universitas IBA Palembang. Peserta berjumlah 40 orang, dan semuanya menjadi responden. Jawaban pre-test dan post-test, menunjukkan ada perubahan jumlah peserta terhadap capaian pembelajaran yaitu ; sikap, pengetahuan, keterampilan umum dan keterampilan khusus. Peserta dengan outcome meningkat 15,625\%, yang tetap/stabil $76,25 \%$ dan peserta dengan outcome menurun $8,125 \%$. Jawaban tersebut diregresi juga untuk mengetahui pengaruh pelatihan terhadap perubahan sikap, pengetahuan, keterampilan umum dan khusus. Hasilnya menunjukkan ada perubahan sikap sebesar $3,1 \%$, pengetahuan $15,8 \%$, keterampilan umum $19,8 \%$ dan keterampilan khusus 0,2\%. Pengaruh ( $\mathrm{R}$ square) memang tidak begitu besar, namun begitu jelas bahwa pelatihan vokasi ada pengaruh terhadap outcome peserta. Dibutuhkan strategi aktifitas terarah ke tujuan (goal directed activity) dan strategi aktifitas tujuan (goal activity) untuk meningkatkan outcome peserta pasca pelatihan, sehingga tujuan menjadi tukang bahan bangunan untuk infrastruktur pembangunan jalan dan permukiman yang kompeten dapat tercapai.
\end{abstract}

Kata Kunci: pelatihan vokasi, perubahan sikap, pengetahuan,keterampilan umum dan keterampilan khusus

\section{Pendahuluan}

Capaian pembelajaran atau outcome para peserta dari suatu pelatihan adalah adanya perubahan perilaku peserta yang disebabkan oleh perubahan sikap, penambahan pengetahuan, peningkatan 
keterampilan umum dan semakin variatif keterampilan khusus peserta. Banyak hasil penelitian yang mengatakan bahwa keempat variabel capaian ini merupakan respon psikologis seseorang yang didapat selama proses pendidikan dan pelatihan, kemudian akan mempengaruhi perilaku orang tersebut. (Robert \& Angelo, 2014).

Artikel ini membahas tentang perubahan perilaku yang terjadi pada para peserta pelatihan bahan bangunan paving blok. Perubahan perilaku tersebut dapat mencerminkan kemampuan dan keterampilan peserta yang semakin baik dan mampu menyelesaikan permasalahan yang terjadi dibidang pekerjaannya. Ketika peserta mengalami permasalahan saat pemasangan paving blok, yaitu susunan tidak pas, penampilan kurang rapi dan kerekatan paving blok yang satu dengan yang lain masih longgar, maka dalam menanggapi permasalahan ini tentu dibutuhkan sikap yang bijak, kemampuan mengeidentifikasi sumber permasalahan, mengevaluasi permalasahan tersebut sehingga dapat menemukan pokok permasalahan. Seseorang yang mempunyai pengetahuan dan keterampilan akan dengan mudah menemukan cara menyelesaikan pokok permalasahan tersebut. Dari kasus tersebut diketahui bahwa proses pengadukan bahan, pemadatan kedalam cetakan kurang baik dan kondisi cetakan belum dibersihkan terlebih dahulu dan belum diberikan minyak pelumas sebelum mencetak, sehingga ada bahan yang masih menempel dicetakan yang menyebabkan sudut paving blok tidak simetris. Seorang yang ahli dapat mengevaluasi pokok permasalahan ini lebih lanjut dengan mengoreksi kesiapan lahan pemasangan. Ketidaktepatan pemasangan paving blok juga dapat disebabkan oleh kurang padatnya lahan (space) untuk pemasangan paving blok. Pemadatan dan perataan tanah tempat memasang paving blok juga membutuhkan keahlian khusus, sehingga saat dilakukan penyusunan paving blok akan mudah mengatur pola untuk mendapatkan desain yang menarik dan indah.

Ketika keempat variabel capaian pembelajaran ini dapat dicapai oleh setiap peserta pelatihan, maka kegiatan pelatihan sudah dianggap efektif. (Kinicki, 2014). Capaian pembelajaran yang telah diperoleh peserta setelah mengikuti pelatihan vokasi tukang bahan bangunan paving blok, dapat dikatakan sebagai outcome atau outcome fase awal. Outcome fase awal bisa terus meningkat menuju outcome fase puncak, bila ada tindak lanjut untuk meningkatkannya. Namun bisa jadi outcome akan stagnan atau bahkan kembali nol, kalau dibiarkan saja tanpa ada rencana tindak lanjut. Memotivasi peserta dengan cara memberikan dorongan semangat bahwa tujuan mereka bukan sebatas pada perolehan outcome fase awal, tapi outcome fase puncak yang harus diperjuangkan untuk dicapai. Menjadi tukang bahan bangunan infrastruktur pembangunan jalan dan permukiman yang kompeten dan menjadi wirausaha yang mandiri adalah tujuan yang harus dicapai. Inilah wujud outcome fase puncak.

\section{Literature Review}

\subsection{Pelatihan vokasi}

Pelatihan adalah proses sistematis mengubah tingkah laku untuk mencapai suatu tujuan yang berkaitan dengan keahlian dan kemampuan untuk melakukan suatu pekerjaan. (Rivai, 2015). Perubahan perilaku yang diharapkan adalah perubahan sikap, pengetahuan dan keterampilan peserta pelatihan baik keterampilan umum maupun khusus. Pelatihan vokasi merupakan proses transfer pengetahuan dan keterampilan dengan durasi waktu yang lebih singkat dengan mempraktekan langsung membuat produk. Pelatihan vokasi untuk menciptakan SDM yang kompeten berproduksi bahan bangunan berbasis kebutuhan industri (dimand driven).

\subsection{Sikap}

Menurut (Moorhead.Griffin, 2013), sikap adalah sekumpulan kepercayaan dan perasaan yang dimiliki seseorang mengenai ide, situasi dan orang lain. Sikap merefleksikan bagaimana pikiran dan perasaan seseorang tentang sesuatu (E.Judge, 2015). Sikap terbentuk dari informasi-informasi yang tersimpan dalam ingatan, pikiran/logika (kognitif) seseorang menjadi suatu pengetahuan (C.Olson, 2016). Kepercayaan dan perasaan, merupakan 2 komponen sikap yaitu komponen kognitif 
(kepercayaan, pemikiran, informasi dalam ingatan) dan komponen afektif (perasaan/emosi). Sikap akan mengarah kepada perilaku bila ada unsur penguat arah (intensi) biasanya berupa tujuan yang akan dicapai. Ketiga komponen ini akan saling berintegrasi untuk membentuk perilaku. (Thoha, 2016). Pada saat seseorang percaya bahwa suatu pekerjaan itu baik bagi dirinya maka orang tersebut akan bersikap positif terhadap pekerjaan tersebut. Begitu juga, ketika seseorang merasakan suatu pekerjaan itu menyenangkan, maka dia akan bersikap positif terhadap pekerjaan tersebut. Perilaku yang positif tentu didukung oleh sikap positif dan intensi untuk mencapai tujuan, sehingga tujuan menjadi daya pendorong yang sangat kuat. (Thoha, 2016).

\subsection{Pengetahuan}

Pengetahuan adalah informasi atau maklumat yang diketahui atau disadari oleh seseorang atau berbagai gejala yang ditemui atau diperoleh manusia melalui pengamatan akal. (Zainal, 2015). Selanjutnya dikatakan, pengetahuan sebagai informasi yang telah dikombinasikan dengan pemahaman dan potensi untuk menindaki, yang melekat dibenak seseorang. Pengetahuan memiliki kemampuan prediktif sehingga mampu mengarahkan perilaku. Misalnya seseorang akan melakukan suatu pekerjaan, tentu akan mengingat kembali informasi yang diketahui berkaitan dengan pekerjaan tersebut, sehingga dia dapat melakukan pekerjaannya.

\subsection{Keterampilan}

Keterampilan sering diartikan sebagai kemampuan dan kecekatan yang dimiliki seseorang dalam mengerjakan dan menyelesaikan sebuah pekerjaan. Menurut (Rivai, 2015), keterampilan merupakan sasaran pelatihan untuk perubahan physical skill, intelectual skill, social skill dan manajerial skill. Keterampilan melatih seseorang melakukan gerakan-gerakan kerja yang cepat dan tepat. Capaian pembelajaran untuk variabel keterampilan dibagi dua yaitu keterampilan umum dan keterampilan khusus.

\section{a. Keterampilan Umum.}

Kemampuan yang diperoleh melalui usaha sistematis, berkelanjutan, adaptif melaksanakan aktifitas yang kompleks atau fungsi pekerjaan yang melibatkan ide/keterampilan kognitif, keterampilan teknikal dan keterampilan interpersonal. (Zainal, 2015). Misalnya seorang peserta pelatihan, setelah mengikuti pelatihan akan mampu memahami, mengerti bagaimana melakukan suatu pekerjaan sesuai dengan teori-teori yang dipelajari selama pelatihan serta mampu menjelaskan kembali urutan-urutan atau SOP pekerjaan yang dikerjakannya.

\section{b. Keterampilan Khusus}

Keterampilan khusus dapat tercermin dari perilaku seseorang yang kompeten dan ahli dalam melakukan pekerjaannya dengan hasil yang baik. Bersikap positif, memiliki pengetahuan dan keterampilan terhadap pekerjaan tersebut. Keterampilan khusus ditunjukkan dari keahlian seseorang untuk menyelesaikan permasalahan yang terjadi dengan pekerjaannya. Mulai dari mengidentifikasi permasalahan, menemukan pokok permasalahan, mengevaluasi kinerja dan mampu melakukan koreksi serta memberikan solusi-solusi baik dan tepat bahkan dengan keahliannya dapat menciptakan sesuatu ide, kreasi dan inovasi baru. Seseorang yang mempunyai keterampilan khusus biasanya juga didasari oleh pengalaman bekerja dibidang yang sama selain pengalaman dari berbagai kegiatan pelatihan.

\section{Metodologi Penelitian}

\subsection{Objek Penelitian}

Objek pada penelitian ini adalah para peserta pelatihan vokasi tukang bahan bangunan paving blok yang berjumlah 40 orang, berdomisili di 11 kelurahan yang ada di Kota Palembang dan merupakan masyarakat yang tergabung dalam kelompok binaan program peningkatan penghidupan masyarakat berbasis komunitas (PPMK) Program KOTAKU, Dirjen Cipta Karya Kementerian Pekerjaan Umum dan Perumahan Rakyat. 


\subsection{Desain Penelitian}

Penelitian yang ditulis dalam bentuk artikel ini didesain secara deskriptif verifikatif, yaitu mengidentifikasi fenomena psikologis peserta setelah mengikuti pelatihan vokasi tukang bahan bangunan paving blok yaitu perubahan sikap, pengetahuan, keterampilan umum dan keterampilan khusus.

\subsection{Operasional Variabel}

Pelatihan vokasi tukang bahan bangunan paving blok sebagai variabel $\mathrm{X}$ (independen) sedangkan ke 4 variabel outcomes merupakan variabel dependen yaitu sikap sebagai variabel Y1, pengetahuan Y2, keterampilan umum Y3 dan keterampilan khusus Y4.

\subsection{Hipotesis Penelitian}

Ha : yaitu ada pengaruh variabel pelatihan vokasi terhadap variabel sikap,pengetahuan, keterampilan umum dan keterampilan khusus peserta.

H0 : yaitu tidak ada pengaruh variabel pelatihan vokasi terhadap variabel sikap,pengetahuan, keterampilan umum dan keterampilan khusus peserta.

\subsection{Metode Pengumpulan Data}

Data yang digunakan adalah data primer berupa pilihan jawaban yang dipilih peserta dalam lembar pernyataan tertutup yang diajukan. Pernyataan dituliskan pada lembar pre-test dan post-test. Lembar pre-test diisi peserta sebelum pelatihan teori dan praktek dimulai, sedangkan lembar post-test diisi peserta setelah mengikuti pelatihan. Pilihan jawaban peserta diasumsikan sebagai gambaran tentang respon psikologis peserta pelatihan vokasi tukang bahan bangunan paving blok sebelum dan sesudah mengikuti pelatihan. Jawaban yang dipilih peserta merupakan pilihan sangat setuju (SS), setuju (S), netral/ragu-ragu (N), tidak setuju (TS) dan sangat tidak setuju (STS) atas pernyataan-pernyataan yang diasumsikan dapat mewakili tentang gambaran sikap, pengetahuan, keterampilan umum dan keterampilan khusus peserta.

Pernyataan-pernyataan yang ada pada pre-test sama persis dengan pernyataan-pernyataan pada posttest. Semua pernyataan merupakan pernyataan positif. Skor untuk pernyataan bila sangat setuju (SS) bernilai 5, setuju (S) bernilai 4, netral/ragu-ragu (N) bernilai 3, tidak setuju (TS) bernilai 2 dan sangat tidak setuju (STS) bernilai 1. Skor setiap pilihan jawaban peserta dijumlahkan kemudian diperbandingkan antara jumlah skor pre-test dan skor post-test untuk 4 variabel capaian pembelajaran, yaitu perubahan sikap, pengetahuan, keterampilan umum dan keterampilan khusus. Ada empat kemungkinan perubahan yang akan diperoleh yaitu perubahan sangat baik, lebih baik, sudah baik dan kurang baik.

\subsection{Teknik Analisis}

Dinamika fenomena psikologis ini dianalisis dengan melihat persentase perubahan jumlah peserta yang mengalami perubahan outcome meningkat yaitu penjumlahan perubahan outcome sangat baik dan lebih baik, perubahan stabil dan menurun yang disajikan dalam bentuk grafik. Pengujian juga dilakukan secara statistik melalui uji regresi linear sederhana.

\section{Hasil dan Pembahasan}

\subsection{Hasil}

Hasil pengolahan data disajikan dalam bentuk grafik distribusi peserta dengan predikat outcome atau perubahan sikap, pengetahuan, keterampilan umum dan keterampilan khusus setelah mendapat pelatihan vokasi. Grafik-grafik ini akan menggambarkan jumlah peserta yang memilih jawaban yang dikatagorikan pada predikat sangat baik, lebih baik, sudah baik dan kurang baik. Berikut grafik yang menggambarkan distribusi tersebut : 
Gambar 1. Grafik Distribusi Peserta dengan Predikat Outcome Sikap

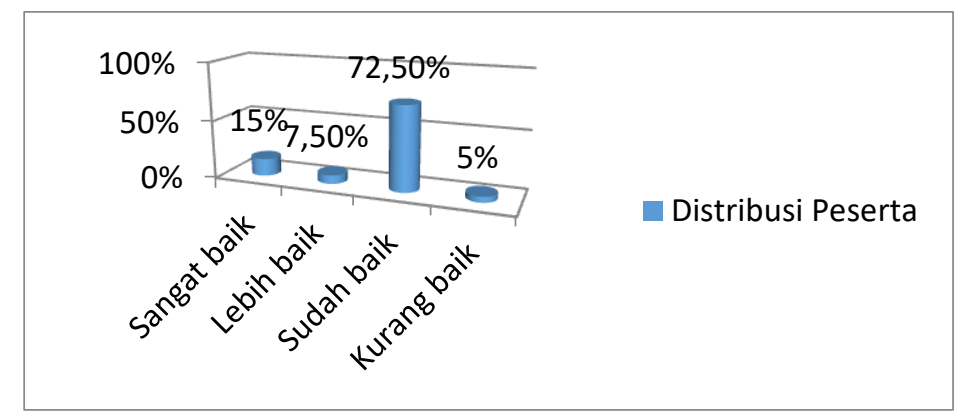

Sumber : Pengolahan Data Pre-test dan Post-test, 2021

Keterangan :

1. Distribusi peserta dengan predikat sangat baik (15\%), lebih baik/ perubahan lambat $(7,5 \%)$ dan sudah baik/perubahan stabil $(72,5 \%)$. Pada kelompok ini tidak ada perubahan sikap namun pada posisi yang sangat baik dari sebelum dan sesudah pelatihan.

2. Distribusi peserta dengan predikat kurang baik (5\%) merupakan perubahan sikap peserta yang semakin menurun/negatif terhadap tujuan pelatihan vokasi. Ada kemungkinan yang menyebabkannya antara lain kurangnya informasi tentang tujuan pelatihan.

Gambar 2. Grafik Distribusi Peserta dengan Predikat Outcome Pengetahuan

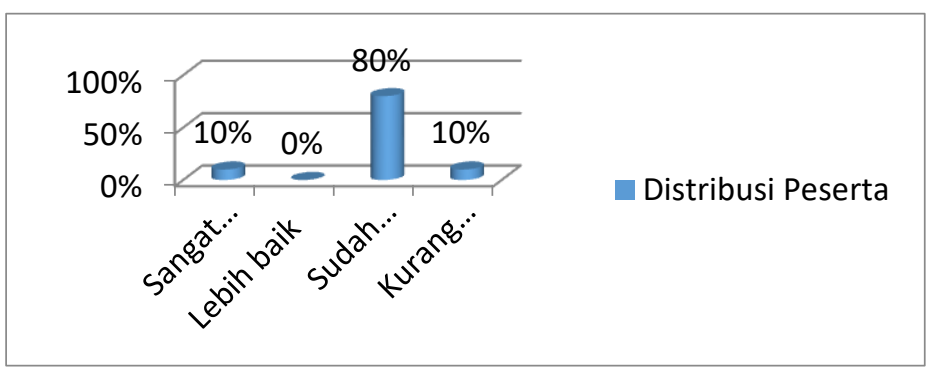

Sumber : Pengolahan Data Pre-test dan Post-test, 2021

Keterangan :

1. Distribusi peserta dengan predikat sangat baik atau perubahan cepat dalam menangkap pengetahuan/informasi (10\%), lebih baik atau perubahan lambat $(0 \%)$ dan sudah baik atau perubahan stabil $(80 \%)$. Trend perubahan pengetahuan peserta semakin positif terhadap tujuan pelatihan vokasi.

2. Distribusi peserta dengan predikat kurang baik (10\%) merupakan perubahan pengetahuan peserta yang semakin menurun/negatif terhadap tujuan pelatihan vokasi. Diduga kelompok ini kurang percaya atau merasa pesimis bahwa meningkatkan pengetahuan dapat mencapai tujuan pelatihan vokasi. Menurunnya perubahan pengetahuan ini dapat dikatakan sebagai lemahnya motivasi peserta.

Gambar 3. Grafik Distribusi Peserta dengan Predikat Outcome Keterampilan Umum

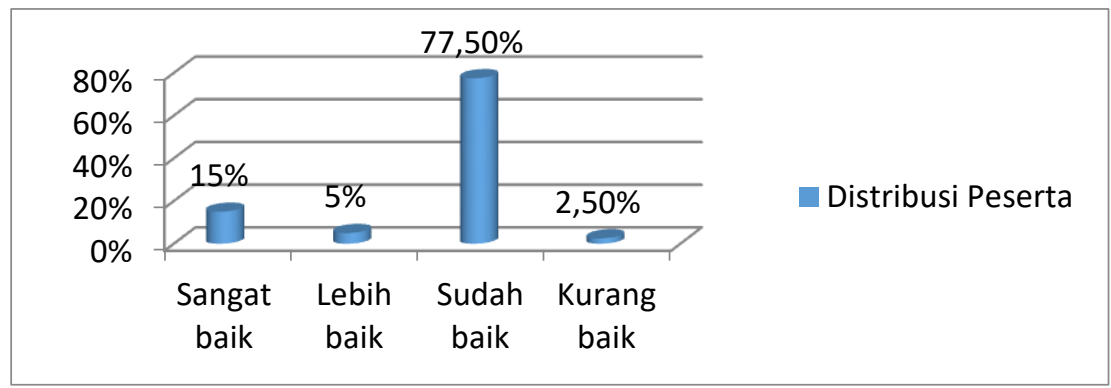

Sumber : Pengolahan Data Pre-test dan Post-test, 2021 
Keterangan :

1. Distribusi peserta dengan predikat sangat baik $(15 \%)$ yaitu trend perubahan yang cepat untuk keterampilan umum. Lebih baik atau perubahan yang lambat $(5 \%)$ dan perubahan sudah baik atau stabil $(77,5 \%)$. Trend perubahan keterampilan umum peserta positif, berarti peserta memahami teori dan praktek.

2. Distribusi peserta dengan predikat kurang baik (2,5\%) menunjukkan perubahan keterampilan umum peserta yang menurun, yang kemungkinan terjadi karena masih ada keraguan peserta untuk mencapai tujuan pelatihan.

Gambar 4. Grafik Distribusi Peserta dengan Predikat Outcome Keterampilan Khusus

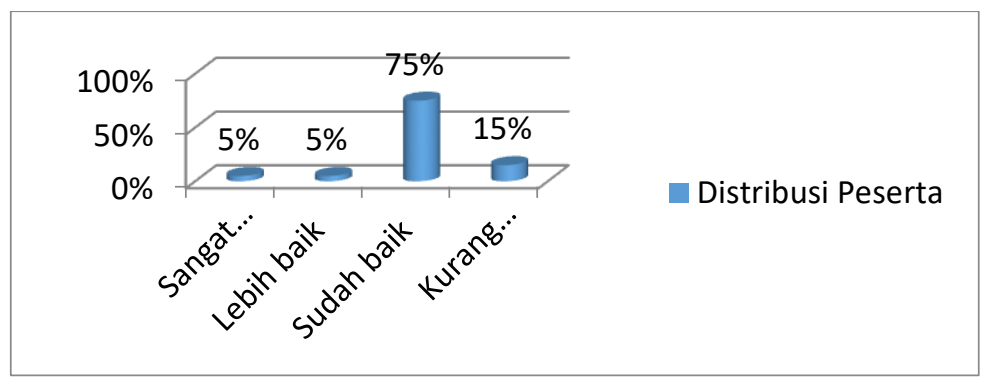

\section{Sumber : Pengolahan Data Pre-test dan Post-test, 2021}

Keterangan :

1. Distribusi peserta dengan predikat sangat baik (5\%), lebih baik (5\%) dan sudah baik (75\%). Trend perubahan keterampilan khusus yang positif menunjukkan bahwa peserta mampu memahami teori dan praktek dengan permasalahannya.

2. Distribusi peserta dengan predikat kurang baik (15\%) menunjukkan perubahan keterampilan khusus peserta menurun. Dengan kata lain peserta belum termotivasi untuk mencapai tujuan pelatihan.

Hasil regresi untuk mengetahui pengaruh pelatihan terhadap sikap, pengetahuan, keterampilan umum dan keterampilan khusus.(SPSS 23) adalah sebagai berikut:

Tabel 1. Koefisien Determinasi Pelatihan Terhadap Sikap

\begin{tabular}{|c|c|c|c|c|c|c|c|c|c|}
\hline \multicolumn{10}{|c|}{ Model Summary } \\
\hline \multirow[b]{2}{*}{ Model } & \multirow[b]{2}{*}{$\mathrm{R}$} & \multirow[b]{2}{*}{ R Square } & \multirow[b]{2}{*}{$\begin{array}{l}\text { Adjusted R } \\
\text { Square }\end{array}$} & \multirow[b]{2}{*}{$\begin{array}{l}\text { Std. Error of } \\
\text { the Estimate }\end{array}$} & \multicolumn{5}{|c|}{ Change Statistics } \\
\hline & & & & & $\begin{array}{c}\text { R Square } \\
\text { Change }\end{array}$ & F Change & df1 & df2 & $\begin{array}{l}\text { Sig. F } \\
\text { Change }\end{array}$ \\
\hline 1 & $176^{\mathrm{a}}$ & .031 &, 005 & 1,29714 & 031 & 1,211 & 1 & 38 & 278 \\
\hline
\end{tabular}

a. Predictors: (Constant), Pelatihan

Sumber : Hasil pengolahan data dengan program SPSS R. 23

Pengaruh variabel pelatihan vokasi $(\mathrm{X})$ terhadap variabel sikap (Y1) ditunjukkan oleh koefisien diterminasi (R square) yaitu sebesar 0,031 artinya kontribusi variabel pelatihan vokasi terhadap variabel sikap hanya sebesar $3,1 \%$ sisanya $96,9 \%$ dipengaruhi oleh factor lain. Faktor tersebut diantaranya bahwa $72,5 \%$ peserta telah memiliki sikap yang sudah baik terhadap pelatihan membuat bahan bangunan paving blok. Peserta yang mengalami perubahan sikap 22,5\% (Gambar 1).

Tabel 2. Model Regresi Pelatihan terhadap Sikap

Coefficients $^{a}$

\begin{tabular}{|c|c|c|c|c|c|c|}
\hline \multirow{2}{*}{\multicolumn{2}{|c|}{ Model }} & \multicolumn{2}{|c|}{ Unstandardized Coefficients } & \multirow{2}{*}{$\begin{array}{c}\begin{array}{c}\text { Standardized } \\
\text { Coefficients }\end{array} \\
\text { Beta }\end{array}$} & \multirow[b]{2}{*}{$\mathrm{t}$} & \multirow[b]{2}{*}{ Sig. } \\
\hline & & $B$ & Std. Error & & & \\
\hline \multirow[t]{2}{*}{1} & (Constant) & 17,722 & 2,233 & & 7,935 & .000 \\
\hline & Pelatihan &,- 149 & .135 &,- 176 & $-1,100$ & .278 \\
\hline
\end{tabular}

a. Dependent Variable: Sikap

Sumber : Hasil pengolahan data dengan program SPSS R. 23 
Keterangan :

a. Model Regresi: $Y_{1}=17,722-0,149 X$

b. Korelasi 0,176 atau $17,6 \%$; korelasi sangat rendah

c. Pengujian hipotesis, $\mathrm{df}=\mathrm{n}-\mathrm{k}=40-2=38$ pada taraf kepercayaan $\alpha=5 \%$ diperoleh $\mathrm{t}$-tabel 2,024 , sedangkan t-hitung 1,100 sehingga t-hitung < t-tabel atau angka Sig. 0,278 > 0,05. Dengan demikian; $\mu=0$ yaitu menerima $\mathrm{H}_{0}$ atau menolak $\mathrm{H}_{\mathrm{a}}$ yaitu tidak ada pengaruh signifikan variabel pelatihan terhadap variabel sikap.

Tabel 3. Koefisien Determinasi Pelatihan Terhadap Pengetahuan

\begin{tabular}{|c|c|c|c|c|c|c|c|c|c|}
\hline \multicolumn{10}{|c|}{ Model Summary } \\
\hline \multirow[b]{2}{*}{ Model } & \multirow[b]{2}{*}{$\mathrm{R}$} & \multirow[b]{2}{*}{ R Square } & \multirow[b]{2}{*}{$\begin{array}{c}\text { Adjusted R } \\
\text { Square }\end{array}$} & \multirow[b]{2}{*}{$\begin{array}{l}\text { Std. Error of } \\
\text { the Estimate }\end{array}$} & \multicolumn{5}{|c|}{ Change Statistics } \\
\hline & & & & & $\begin{array}{c}\text { R Square } \\
\text { Change }\end{array}$ & F Change & df1 & $\mathrm{df} 2$ & $\begin{array}{c}\text { Sig. F } \\
\text { Change }\end{array}$ \\
\hline 1 & $398^{\mathrm{a}}$ &, 158 &, 136 & 1,77847 & 158 & 7,140 & 1 & 38 & 011 \\
\hline
\end{tabular}

Sumber : Hasil pengolahan data dengan program SPSS R. 23

Pengaruh variabel pelatihan vokasi (X) terhadap variabel pengetahuan (Y2) ditunjukkan oleh koefisien diterminasi ( $\mathrm{R}$ square) yaitu sebesar 0,158 artinya kontribusi variabel pelatihan vokasi terhadap variabel pengetahuan hanya sebesar $15,8 \%$ sisanya $84,2 \%$ dipengaruhi oleh factor lain. Faktor tersebut diantaranya bahwa $80 \%$ peserta telah memiliki pengetahuan yang sudah baik tentang membuat bahan bangunan paving blok. Peserta yang mengalami penambahan pengetahuan hanya $10 \%$ dan yang menurun atau tidak termotivasi $10 \%$.(gambar 4.2).

Tabel 4. Model Regresi Pelatihan terhadap Pengetahuan

\begin{tabular}{|c|c|c|c|c|c|c|}
\hline \multicolumn{7}{|c|}{ Coefficients $^{a}$} \\
\hline \multirow[b]{2}{*}{ Model } & & \multicolumn{2}{|c|}{ Unstandardized Coefficients } & \multirow{2}{*}{$\begin{array}{c}\begin{array}{c}\text { Standardized } \\
\text { Coefficients }\end{array} \\
\text { Beta }\end{array}$} & \multirow[b]{2}{*}{$t$} & \multirow[b]{2}{*}{ Sig. } \\
\hline & & $B$ & Std. Error & & & \\
\hline \multirow[t]{2}{*}{1} & (Constant) & 7,527 & 3,062 & & 2,458 & .019 \\
\hline & Pelatihan & .496 &, 186 & ,398 & 2,672 & 011 \\
\hline
\end{tabular}

Sumber : Hasil pengolahan data dengan program SPSS R. 23

Keterangan:

a. Model Regresi: $Y_{2}=7,527+0,496 X$

b. Korelasi 0,398 atau $39,8 \%$; korelasi rendah

c. Pengujian hipotesis, $\mathrm{df}=\mathrm{n}-\mathrm{k}=40-2=38$ pada taraf kepercayaan $\alpha=5 \%$ diperoleh t-tabel 2,024 , sedangkan t-hitung 2,672 sehingga t-hitung >t-tabel atau angka Sig. 0,011>0,05. Dengan demikian; $\mu \neq 0$ yaitu menolak $\mathrm{H}_{0}$ atau menerima $\mathrm{H}_{\mathrm{a}}$ yaitu terdapat pengaruh signifikan variabel pelatihan terhadap variabel pengetahuan.

Tabel 5. Koefisien Determinasi Pelatihan Terhadap Keterampilan Umum

Model Summary

\begin{tabular}{|c|c|c|c|c|c|c|c|c|c|}
\hline \multirow[b]{2}{*}{ Model } & \multirow[b]{2}{*}{$\mathrm{R}$} & \multirow[b]{2}{*}{ R Square } & \multirow[b]{2}{*}{$\begin{array}{l}\text { Adjusted R } \\
\text { Square }\end{array}$} & \multirow[b]{2}{*}{$\begin{array}{l}\text { Std. Error of } \\
\text { the Estimate }\end{array}$} & \multicolumn{5}{|c|}{ Change Statistics } \\
\hline & & & & & $\begin{array}{c}\text { R Square } \\
\text { Change }\end{array}$ & F Change & df1 & $\mathrm{df} 2$ & $\begin{array}{l}\text { Sig. F } \\
\text { Change }\end{array}$ \\
\hline 1 & $.445^{\mathrm{a}}$ & ,198 & 177 & 1,18976 & 198 & 9,403 & $\overline{1}$ & 38 &, 004 \\
\hline
\end{tabular}

a. Predictors: (Constant), Pelatihan

Sumber : Hasil pengolahan data dengan program SPSS R. 23

Pengaruh variabel pelatihan vokasi (X) terhadap variabel keterampilan umum (Y3) ditunjukkan oleh koefisien diterminasi ( $\mathrm{R}$ square) yaitu sebesar 0,198 artinya kontribusi variabel pelatihan vokasi terhadap variabel keterampilan umum hanya sebesar $19,8 \%$ sisanya $81,2 \%$ dipengaruhi oleh factor 
lain. Faktor tersebut diantaranya bahwa 77,5\% peserta telah memiliki keterampilan umum yang sudah baik sehingga tidak terjadi perubahan terhadap keterampilan umum membuat bahan bangunan paving blok. Peserta yang mengalami penambahan keterampilan umum $20 \%$ dan yang menurun atau tidak termotivasi 2,5\% (gambar 4.3).

Tabel 6. Model Regresi Pelatihan terhadap Keterampilan Umum

\begin{tabular}{|c|c|c|c|c|c|c|}
\hline \multicolumn{7}{|c|}{ Coefficients $^{a}$} \\
\hline \multirow{2}{*}{\multicolumn{2}{|c|}{ Model }} & \multicolumn{2}{|c|}{ Unstandardized Coefficients } & \multirow{2}{*}{$\begin{array}{c}\begin{array}{c}\text { Standardized } \\
\text { Coefficients }\end{array} \\
\text { Beta }\end{array}$} & \multirow[b]{2}{*}{$\mathrm{t}$} & \multirow[b]{2}{*}{ Sig. } \\
\hline & & $B$ & Std. Error & & & \\
\hline \multirow[t]{2}{*}{1} & (Constant) & 9,395 & 2,049 & & 4,586 & .000 \\
\hline & Pelatihan & 381 & 124 & 445 & 3,066 &, 004 \\
\hline
\end{tabular}

Sumber : Hasil pengolahan data dengan program SPSS R. 23

Keterangan:

a. Model Regresi: $Y_{3}=9,395+0,381 X$

b. Korelasi 0,445 atau $44,5 \%$; korelasi sedang

c. Pengujian hipotesis, $\mathrm{df}=\mathrm{n}-\mathrm{k}=40-2=38$ pada taraf kepercayaan $\alpha=5 \%$ diperoleh t-tabel 2,024 , sedangkan t-hitung 3,066 sehingga t-hitung $>$ t-tabel atau angka Sig. 0,04 $<0,05$. Dengan demikian; $\mu \neq 0$ yaitu menolak $\mathrm{H}_{0}$ atau menerima $\mathrm{H}_{\mathrm{a}}$ yaitu terdapat pengaruh signifikan variabel pelatihan terhadap variabel keterampilan umum.

Tabel 7. Koefisien Determinasi Pelatihan Terhadap Keterampilan Khusus

\begin{tabular}{|c|c|c|c|c|c|c|c|c|c|}
\hline \multirow[b]{3}{*}{ Model } & \multirow[b]{3}{*}{$\mathrm{R}$} & \multicolumn{7}{|c|}{ Model Summary } & \\
\hline & & \multirow[b]{2}{*}{ R Square } & \multirow[b]{2}{*}{$\begin{array}{c}\text { Adjusted R } \\
\text { Square }\end{array}$} & \multirow[b]{2}{*}{$\begin{array}{l}\text { Std. Error of } \\
\text { the Estimate }\end{array}$} & \multicolumn{5}{|c|}{ Change Statistics } \\
\hline & & & & & $\begin{array}{c}\text { R Square } \\
\text { Change }\end{array}$ & F Change & df1 & df2 & $\begin{array}{l}\text { Sig. F } \\
\text { Change }\end{array}$ \\
\hline 1 &, $040^{\mathrm{a}}$ &, 002 &,- 025 & 1,61769 &, 002 &, 060 & 1 & 38 &, 808 \\
\hline
\end{tabular}

a. Predictors: (Constant), Pelatihan

Sumber : Hasil pengolahan data dengan program SPSS R. 23

Penjelasan :

Pengaruh variabel pelatihan vokasi (X) terhadap variabel keterampilan khusus (Y4) ditunjukkan oleh koefisien diterminasi ( $\mathrm{R}$ square) yaitu sebesar 0,002 artinya kontribusi variabel pelatihan vokasi terhadap variabel keterampilan khusus hanya sebesar $0,2 \%$ sisanya $99,8 \%$ dipengaruhi oleh factor lain. Faktor tersebut diantaranya bahwa $75 \%$ peserta telah memiliki keterampilan khusus yang sudah baik sehingga tidak terjadi perubahan terhadap keterampilan khusus membuat bahan bangunan paving blok. Peserta yang mengalami penambahan keterampilan umum $10 \%$, sedangkan menurun atau tidak termotivasi $15 \%$ (gambar 4.4).

Tabel 8. Model Regresi Pelatihan terhadap Keterampilan Khusus

Coefficients $^{a}$

\begin{tabular}{|c|c|c|c|c|c|c|}
\hline \multirow{2}{*}{\multicolumn{2}{|c|}{ Model }} & \multicolumn{2}{|c|}{ Unstandardized Coefficients } & \multirow{2}{*}{$\begin{array}{c}\begin{array}{c}\text { Standardized } \\
\text { Coefficients }\end{array} \\
\text { Beta }\end{array}$} & \multirow[b]{2}{*}{$t$} & \multirow[b]{2}{*}{ Sig. } \\
\hline & & $B$ & Std. Error & & & \\
\hline \multirow[t]{2}{*}{1} & (Constant) & 16,080 & 2,785 & & 5,773 & .000 \\
\hline & Pelatihan &,- 041 & .169 &,- 040 &,- 245 & 808 \\
\hline
\end{tabular}

Sumber : Hasil pengolahan data dengan program SPSS R. 23

Keterangan:

a. Model Regresi: $Y_{4}=16,080-0,041 X$

b. Korelasi 0,040 atau $4,0 \%$; korelasi sangat rendah 
c. Pengujian hipotesis, $\mathrm{df}=\mathrm{n}-\mathrm{k}=40-2=38$ pada taraf kepercayaan $\alpha=5 \%$ diperoleh $\mathrm{t}$-tabel 2,024 , sedangkan t-hitung 0,245 sehingga t-hitung $<\mathrm{t}$-tabel atau angka Sig. 0,808<0,05. Dengan demikian; $\mu=0$ yaitu menerima $\mathrm{H}_{0}$ atau menolak $\mathrm{H}_{\mathrm{a}}$ yaitu tidak terdapat pengaruh signifikan variabel pelatihan terhadap variabel keterampilan khusus.

\subsection{Pembahasan}

1. Distribusi peserta yang mengalami perubahan capaian pembelajaran yang positif cukup besar dibandingkan dengan perubahan capaian pembelajaran yang negatif. Distribusi yang paling besar yaitu peserta yang sudah baik, dimana saat pre-test sampai post-test perubahan tetap stabil pada posisi nilai yang baik. Pada variabel sikap, peserta yang mengalami perubahan positif sebesar $22,5 \%$, stabil/tetap $72,5 \%$, sedangkan yang negatif $5 \%$. Pada variabel pengetahuan, peserta yang mengalami perubahan positif sebesar $10 \%$, yang stabil/tetap $80 \%$, sedangkan yang negatif $10 \%$. Pada variabel keterampilan umum, peserta yang mengalami perubahan positif sebesar $20 \%$, yang stabil/tetap $77,5 \%$, sedangkan yang negatif $2,5 \%$. Pada variabel keterampilan khusus, peserta yang mengalami perubahan positif sebesar $10 \%$, yang stabil/tetap $75 \%$, sedangkan yang negatif $15 \%$.

2. Hasil data ini menunjukkan bahwa peserta pelatihan yang mengalami perubahan sikap, pengetahuan, keterampilan umum dan keterampilan khusus (outcome) yang meningkat positif secara rata-rata sebesar $15,625 \%$, yang stabil secara rata-rata sebesar $76,25 \%$ sedangkan yang menurun secara rata-rata sebesar $8,125 \%$. Dengan kata lain, peserta yang mengalami perubahan outcome tidak terlalu banyak, karena sebagian besar peserta memang sudah memiliki pengetahuan dan keterampilan membuat paving blok. Sedangkan peserta yang mengalami penurunan, dapat dianggap sebagai peserta yang kurang termotivasi untuk menekuni usaha ini.

3. Analisis regresi sederhana menunjukkan bahwa pengaruh pelatihan vokasi $(\mathrm{X})$ terhadap perubahan sikap (Y1) sebesar 3,1\%, perubahan pengetahuan (Y2) sebesar 15,8\%, perubahan keterampilan umum (Y3) sebesar 19,8\% dan perubahan keterampilan khusus (Y4) sebesar 0,2\%.

4. Outcome yang dicapai peserta ini harus terus dipelihara supaya tidak padam. Dibutuhkan solusi yaitu strategi aktifitas terarah ke tujuan (goal directed activity) dan aktifitas tujuan (goal activity), diharapkan peserta yang mengalami perubahan outcome atau outcome fase awal yang meningkat akan menjadi orang-orang yang dapat mencapai outcome fase berikutnya atau fase puncak. Peserta dengan perubahan outcome yang menurun dengan strategi ini diharapkan dapat termotivasi untuk meningkatkan perubahan outcome.

5. Strategi aktifitas terarah ke tujuan (goal directed activity) yaitu perilaku yang dimotivasikan mengarah kepada pencapaian tujuan (Thoha, 2016). Misalnya ketika peserta merasa bahwa menjadi tukang bahan bangunan infrastruktur jalan dan permukiman yang kompeten adalah suatu kebutuhan, maka yang bersangkutan akan mengarahkan perilakunya berada dalam aktifitasaktifitas yang mendukung untuk mencapai tujuan tersebut. Peserta akan berupaya selalu terlibat di dalam kegiatan-kegiatan pembangunan infrastruktur jalan dan permukiman yang dikelola oleh Program KOTAKU Kementerian PUPR atau pihak-pihak swasta. Keterlibatan ini akan mengkondisikan mereka terikat pada aktifitas terarah ke tujuan. Keterlibatan pekerjaan (job involvement) adalah sebagai tingkatan dimana seseorang terlibat, terikat dan berhubungan dengan pekerjaan-pekerjaan sesuai dengan kompetensinya.( (Kinicki, 2014). Keterlibatan pekerjaan (job involvement) dapat juga dikatakan sebagai tingkat dimana seseorang mengidentifikasi dengan sebuah pekerjaan, secara aktif berpartisipasi di dalamnya, dan mempertimbangkan bahwa kinerja penting bagi nilai dirinya. (E.Judge, 2015). Selanjutnya dikatakan keterlibatan pekerjaan meningkatkan kepercayaan pekerja bahwa mereka mempengaruhi lingkungan karena kompetensinya sehingga pekerjaan memberikan arti/nilai dan otonomi bagi mereka atau dinamakan pemberdayaan psikologis (psychological empowerment). Lamanya waktu dan tingginya frekuensi keterlibatan peserta pada bidang pekerjaan yang sesuai dengan kompetensinya maka semakin tinggi nilai keahlian dan kemandirian peserta tersebut. Dukungan dari program KOTAKU dan stakeholders lain dengan memberikan kesempatan hasil produksi mereka untuk digunakan sebagai salah satu material yang dibutuhkan untuk pembangunan infrastruktur jalan dan permukiman program KOTAKU, adalah salah cara melibatkan mereka untuk melakukan aktifitas 
terarah ke tujuan (goal directed activity). Bantuan modal dan peluang pasar, membantu membangunan kekuatan dan jaringan bagi persiapan menjadi wirausaha mandiri.

6. Strategi aktifitas tujuan (goal activity)

Strategi aktifitas tujuan (goal activity) yaitu aktifitas yang terikat pada tujuan tersebut (Thoha, 2016). Misalnya untuk menjadi tukang bahan bangunan yang kompeten, peserta harus fokus pada kegiatan-kegiatan yang berkenaan pelaksanaan tujuan yaitu mengimplentasikan kompetensi tersebut sehingga memberikan nilai bagi dirinya. Nilai tersebut akan tampak pada perilaku kerja mereka. Perilaku kerja tersebut diantaranya ;

a. Disiplin pada penerapan standar kerja untuk menjaga kualitas hasil kerja.

b. Kreatif dalam mengkombinasikan bahan-bahan untuk menghasilkan produk bahan bangunan berkualitas dan inovatif.

c. Berupaya melakukan efisiensi dengan mengoptimalkan sumberdaya yang ada.

d. Percaya diri dan mampu berusaha mandiri.

\section{Simpulan dan Saran}

Berdasarkan hasil penelitian dapat disimpulkan bahwa :

a. Hasil pelatihan menunjukkan hasil yang baik dimana capaian pembelajaran yaitu perubahan outcome dapat tercapai dengan demikian kegiatan pelatihan dapat dikatakan cukup efektif.

b. Tujuan pelatihan belum tercapai karena hasil pelatihan ini hanya sampai pada perubahan outcome, harus ada strategi untuk mencapai tujuan tersebut.

c. Peserta yang kompeten sudah teridentifikasi dan potensial untuk mencapai tujuan tersebut yaitu menjadi tukang bahan bangunan infrastruktur pembangunan jalan dan permukiman yang kompeten dan menjadi wirausaha yang mandiri.

d. Perubahan Outcome pasca pelatihan, jangan berhenti sampai sebatas selesai pelatihan, tetapi harus ada rencana strategi selanjutnya yaitu strategi aktifitas terarah ke tujuan (goal directed activity) dan strategi aktifitas tujuan (goal activity).

\section{Daftar Pustaka}

C.Olson, J. P. (2016). Perilaku Konsumen dan Strategi Pemasaran . Jakarta: Salemba Empat.

E.Judge, S. P. (2015). Perilaku Organisasi. Jakarta: Salemba Empat.

Kinicki, R. K. (2014). Perilaku Organisasi. Jakarta: Salemba Empat.

Moorhead.Griffin. (2013). Perilaku Organisasi (Manajemen Sumberdaya Manusia dan Organisasi). Jakarta: Salemba Empat.

Rivai, V. (2015). Manajemen Sumberdaya Manusia Untuk Perusahaan (dari teori ke praktek). Jakarta: RajaGrafindo Persada.

Robert, k., \& Angelo, K. (2014). Perilaku Organisasi. Jakarta: Salemba Empat.

Thoha, M. (2016). Perilaku Organisasi (Konsep Dasar dan Aplikasinya). Jakarta: RajaGrafindo persada.

Zainal, V. R. (2015). Manajemen Sumberdaya Manusia untuk Perusahaan. Jakarta: Rajagrafindo. 